\title{
Kinerja belanja modal Provinsi Riau: Struktur rasio dan tren
}

\section{Imam Mustaqim* \& Taryono}

Fakultas Ekonomi dan Bisnis, Universitas Riau, Indonesia

\begin{abstract}
Abstrak: Kajian ini untuk menganalisis tren, struktur dan rasio belanja modal. Objek kajian adalah atas belanja modal pemerintah Provinsi Riau tahun 2007 - 2017. Metode analisis menggunakan rasio belanja modal terhadap total belanja, belanja modal per kapita dan rasio terhadap PDRB. Belanja modal tahun 2007-2017 berfluktuasi meningkat. Belanja modal terendah terjadi pada tahun 2014. Alokasi belanja modal paling banyak untuk jalan, irigasi dan jaringan. Rasio belanja modal terhadap total belanja tertinggi pada tahun 2007 sebesar 40,48\% dan terrendah terjadi pada 2014 sebesar 11,13\%. Pada tahun 2014 belanja modal per kapita hanya sebesar Rp. o,10 juta rupiah, meningkat di tahun 2015 dan menurun pada tahun selanjutnya. Rasio belanja modal terhadap PDRB mengalami trend yang menurun di setiap tahunnya pada tahun 2014 paling rendah sebesar $0,32 \%$ dan tertinggi terjadi pada tahun 2015 sebesar 0,59\%.
\end{abstract}

Katakunci: struktur; rasio belanja modal; belanja modal per kapita

\begin{abstract}
This study is to analyze trends, structure and capital expenditure ratios. The object of study is the capital expenditure of the Riau Province government in 2007-2017. The analysis method uses the ratio of capital expenditure to total expenditure, capital expenditure per capita and ratio to GRDP. Capital expenditure in 2007-2017 has fluctuated. The lowest capital expenditure occurred in 2014. The most capital expenditure allocation for roads, irrigation and networks. The highest ratio of capital expenditure to total expenditure in 2007 was $40.48 \%$ and the lowest occurred in 2014 of $11.13 \%$. In 2014 capital expenditure per capita was only Rp. o.10 million rupiah, an increase in 2015 and decrease in the following year. The ratio of capital expenditure to GRDP experienced a declining trend every year in 2014, the lowest of $0.32 \%$ and the highest occurred in 2015 of $0.59 \%$.
\end{abstract}

Keywords: structure; capital expenditure ratio; capital expenditure per capita

JEL Classification: $\mathrm{H}_{11}, \mathrm{H}_{54}, \mathrm{H}_{72}, \mathrm{H}_{76}$ 


\section{PENDAHULUAN}

Tahun 1999 menjadi salah satu babak baru bagi hubungan antara pemerintah pusat dan pemerintah daerah. Pemerintahan yang awalnya berkiblat pada sentralisasi berubah menjadi sistem desentralisasi. Adanya otonomi daerah yang membawa sistem pemerintahan yang mengacu pada sistem desentralisasi maka terjadi pembaharuan dan evolusi dalam berbagai bidang pemerintahan, termasuk dalam bidang keuangan pemerintah daerah. Di bidang keuangan daerah, pemerintah mengadopsi manajemen sektor swasta di beberapa negara maju, hubungan pemerintah dan pemerintah daerah (Lapsley \& Pallot, 2002; Almquist et al., 2013; Adhikari et al., 2015; Fryer et al., 2009).

Untuk mendukung jalannya pemerintah yang mandiri, maka pemerintah daerah perlu mencari dan mengidentifikasi sumber-sumber daya yang ada di daerah. Pelayanan publik menjadi salah satu indikator bagi penilaian kinerja pemerintah dalam mengemban amanah dari rakyat. Salah satu tolok ukur layanan pemerintah daerah kepada publik adalah keberadaan fasilitas publik yang dialokasikan dalam anggaran daerah dalam item pengeluaran modal (Lapsley et al., 2010).

Alokasi belanja modal didasarkan pada kebutuhan daerah untuk fasilitas dan infrastruktur untuk pemerintah dan fasilitas publik. Setiap periode anggaran untuk pengadaan aset tetap pemerintah daerah didasarkan pada prioritas anggaran dan layanan publik yang memiliki dampak jangka panjang (Kelly \& Rivenbank, 2011).

Dalam praktik penganggaran daerah, alokasi sumber daya anggaran adalah proses yang penuh dengan kepentingan politik (Chang, 2009; Jones \& Pendlebury, 2000). Anggaran modal ditujukan untuk memenuhi kebutuhan publik akan fasilitas publik yang disediakan oleh pemerintah daerah. Keterlibatan badan legislatif dengan kepentingan politik mereka dalam proses penganggaran seringkali menyebabkan alokasi belanja modal menjadi terdistorsi dan tidak efektif dalam menyelesaikan masalah di masyarakat (Keefer \& Khemani, 2003).

Sebagai bagian dari APBD, belanja daerah dapat dikelompokkan menjadi dua jenis yaitu belanja tidak langsung dan belanja langsung. Belanja tidak langsung meliputi belanja pegawai, belanja bunga, belanja subsidi, belanja hibah, belanja bantuan social belanja bagi hasil kepada Provinsi/Kabupaten dan pemerintah desa, belanja bantuan keuangan kepada Provinsi/Kabupaten dan pemerintah desa. Sedangkan belanja langsung meliputi belanja pegawai, barang dan jasa, belanja modal (Gorahe et al., 2013).

Sebagai bagian dari belanja langsung, belanja modal merupakan pengeluaran yang dilakukan dalam rangka pembentukan modal yang sifatnya menambah aset tetap/investasi yang memberikan manfaat lebih dari satu periode, termasuk di dalamnya adalah pengeluaran untuk biaya pemeliharaan yang sifatnya mempertahankan atau menambah masa manfaat, meningkatkan kapasitas dan kualitas aset (Suryani \& Eka, 2018).

Sarana dan prasarana yang memadai maka masyarakat dapat melakukan aktivitas sehari-harinya secara aman dan nyaman yang akan berpengaruh pada tingkat produktivitasnya yang semakin meningkat, dengan adanya infrastruktur yang memadai akan menarik investor untuk membuka usaha di daerah tersebut. Jadi dapat di simpulkan bahwa untuk meningkatkan perekonomian suatu daerah di perlukan belanja modal yang meningkat setiap tahunnya (Meirene et al., 2014).

Belanja modal dalam APBD merupakan komponen belanja yang sangat penting karena realisasi atas belanja modal yang dilaksanakan pemerintah daerah akan 
memiliki multiplier effect untuk menggerakkan roda perekonomian daerah. Oleh sebab itu, semakin tinggi angka rasio belanja modal dalam struktur APBD, diharapkan akan semakin baik pengaruhnya terhadap pertumbuhan ekonomi (Sugiyanta, 2016; Yuliastati, 2017).

\section{BELANJA DAERAH}

Pada tahap awal perkembangan ekonomi menurut WW.Rostow dan RA. Musgrave, rasio investasi pemerintah terhadap investasi total dengan kata lain rasio belanja daerah terhadap pendapatan nasional relatif besar. karena pemerintah harus menyediakan berbagai sarana dan prasarana. Pada tahap menengah pembangunan ekonomi, investasi pemerintah tetap diperlukan guna memacu pertumbuhan agar dapat lepas landas. Bersamaan dengan itu porsi investasi pihak swasta juga meningkat. Tahap besarnya peranan pemerintah adalah karena pada tahap ini banyak terjadi kegagalan pasar yang ditimbulkan oleh perkembangan ekonomi itu sendiri (Swaramarinda \& Indriani, 2011).

Daerah yang memiliki potensi sumberdaya yang dapat diandalkan, baik sumberdaya manusia maupun sumberdaya alam kebijakan otonomi daerah disambut baik, karena terbuka peluang bagi pemerintah daerah untuk mengelola daerahnya secara mandiri termasuk dalam hal pengelolaan keuangan daerah. Salah satu harapan dari kebijakan tersebut adalah daerah diberi kesempatan untuk mempercepat perumbuhan ekonomi dan memperhatikan kesejahteraan masyarakat. Sebaliknya bagi daerah yang memiliki keterbatasan sumberdaya, kebijakan demikian akan berantakan. Daerah yang tidak memiliki potensi sumberdaya dalam hal sumber keuangan atau dana yang melimpah akan mengalami kesulitan dalam membiayai belanja daerahnya (Tuasikal, 2008).

Perbelanjaan agregat merupakan penggerak utama dalam perekonomian, sedangkan output agregat yang menunjukkan nilai atas output nasional pada setiap dan seluruh tingkat pendapatan nasional adalah bersifat pasif dan berubah-ubah berdasarkan pembelanjaan agregat (Bado, 2016).

\section{TREN BELANJA MODAL}

Tren belanja modal umumnya positif dan kecendrungannya meningkat (Mahmudi, 2009). Tren belanja modal dan total belanja daerah Provinsi Riau tahun 2007-2017 dapat dilihat dari Gambar 1. 


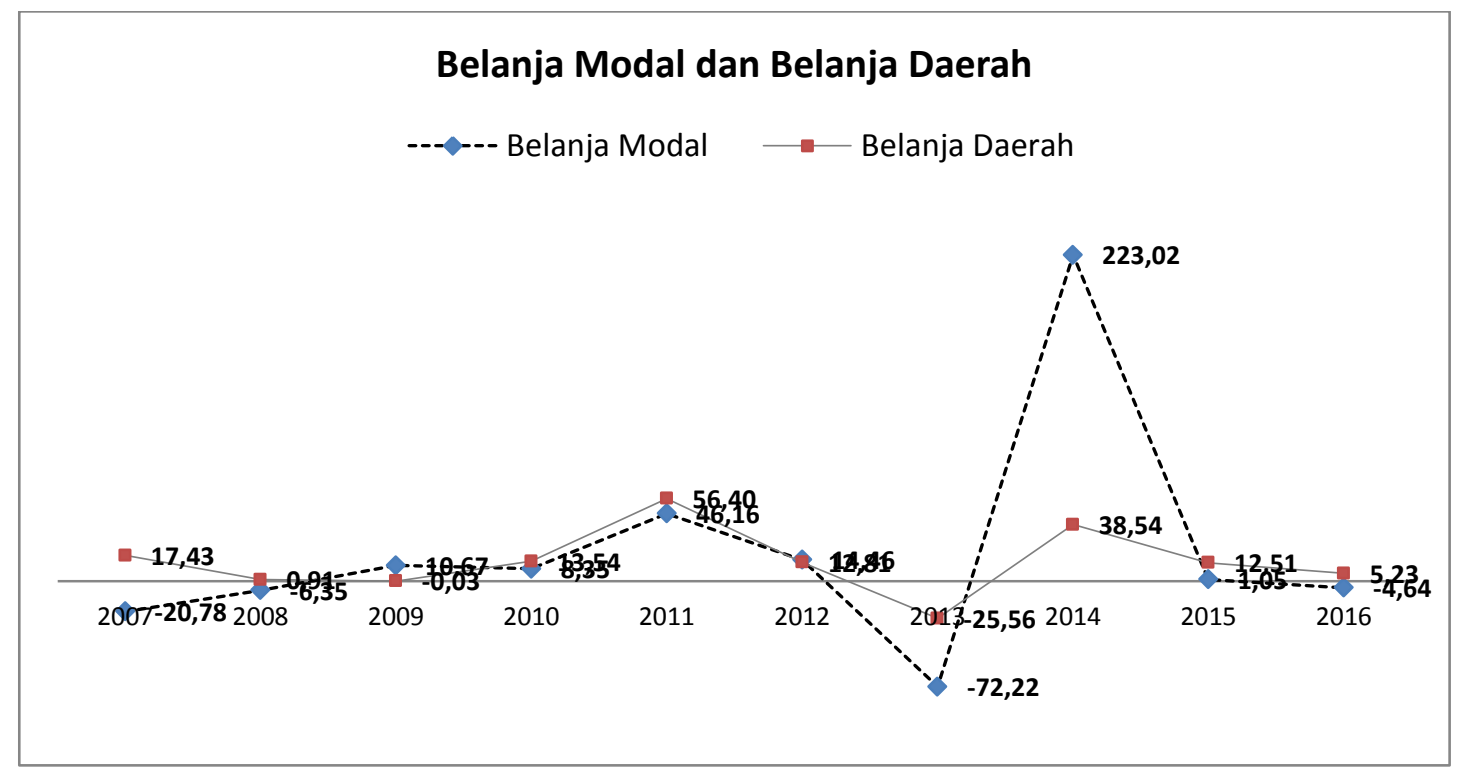

Sumber: Badan Pusat Statistik Provinsi Riau (Riau Dalam Angka), 2018

Gambar 1. Tren Belanja Modal Provinsi Riau Tahun 2008-2017

Belanja modal merupakan pengeluaran pemerintah yang mencerminkan pengeluaran dalam bentuk pembelian atau penggadaan atau pembangunan aset tetap berwujud yang digunakan untuk menunjang kegiatan pemerintah seperti tanah, peralatan dan mesin, gedung dan bangunan, jalan, irigasi dan aset tetap lainnya. Dengan ini perlu ada kebijakan yang cepat dan tepat dari pemerintah daerah. Melalui belanja modal ini diharapkan mampu menciptakan pembangunan ekonomi yang berdampak pada peningkatan kesejahteraan masyarakat, kemajuan daerah itu sendiri dan menjadi daerah yang mandiri agar infrastruktur baik jalan maupun yang lainnya dapat langsung dirasakan oleh masyarakat (Bado, 2016).

\section{Struktur Belanja Modal Provinsi Riau Tahun 2007-2017}

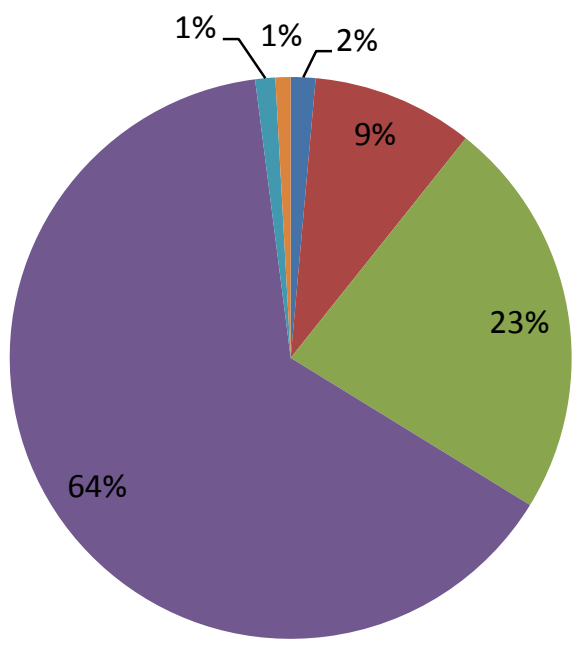

- Tanah

- Peralatan dan mesin

Gedung dan Bangunan

- Jalan, Irigasi dan Jaringan

Aset tetap lainnya

Aset lainnya

Sumber: Badan Pusat Statistik Provinsi Riau (Riau Dalam Angka), 2018

Gambar 2. Alokasi Belanja Modal Provinsi Riau Tahun 2007-2017 
Tren belanja modal secara keseluruhan di Provinsi Riau Tahun 2007-2017 berfluktuasi meningkat, pada beberapa tahun belanja modal mengalami peningkatan yang cukup baik, namun ada pula beberapa tahun yang belanja modal mengalami penurunan, dimana pertumbuhan belanja modal terendah terjadi pada tahun 2014 sebesar $-72,22 \%$ dengan total belanja modal Rp. 623.644,30 juta rupiah, sedangkan pertumbuhan belanja modal tertinggi terdapat pada tahun 2015 yaitu $223,01 \%$ dengan total belanja modal sebesar Rp. 2.014.487,68 juta rupiah. Namun di tahun 2008, 2009, 2014 dan 2017 belanja modal juga mengalami penurunan dikarenakan realisasi belanja modal pada tahun tersebut mengalami penurunan dari tahun sebelumnya.

Belanja modal terbagi menjadi enam bagian di antaranya belanja modal tanah, peralatan dan mesin, gedung dan bangunan, jalan irigasi dan jaringan, aset tetap lainnya, dan aset lainnya. Belanja modal Provinsi Riau tahun 2007-2017 lebih banyak dialokasikan pada belanja modal jalan, irigasi dan jaringan di tahun 2007 belanja modal jalan, irigasi dan jaringan sebesar $\mathrm{Rp}$. 760.740,24 juta rupiah sedangkan belanja modal tanah Rp. 43.071,44 juta rupiah, belanja modal peralatan dan mesin sebesar Rp. 189.908,02 juta rupiah, belanja modal gedung dan bangunan Rp. 464.840.077,08 juta rupiah, asset tetap lainnya Rp. 33.713,31 juta rupiah dan asset lainnya $\mathrm{Rp}$. $16.451,85$ juta rupiah. Hal ini terjadi setiap tahun hingga tahun 2017 dimana belanja modal jalan irigasi dan jaringan lebih besar alokasinya dari pada alokasi belanja modal lain.

Banyaknya dana yang dialokasikan untuk belanja modal maka nantinya dapat mewujudkan terciptanya infrastruktur dan sarana yang semakin banya pula. Semakin banyak pembangunan yang di kerjakan oleh pemerintah maka nantinya dapat pula meningkatkan pertumbuhan kinerja keuangan daerah, dapat disimpulkan jika sumber yang dihasilkan berlimpah maka nantinya hasil yang didapat juga akan berlimpah. Selain untuk mengembangkan infrastruktur industri belanja modal juga ditujukan memberikan layanan pada masyarakat yaitu salah satunya melalui infrastruktur jasa (Astiti \& Mimba, 2016).

Pertumbuhan belanja modal Provinsi Riau tahun 2007-2017 mengalami fluktuasi dengan trend menurun, namun di tahun 2014 belanja modal mengalami penurunan yang sangat rendah di bandingkan dengan tahun lainnya sebesar -72,22 $\%$ dengan total belanja belanja modal sebesar $\mathrm{Rp}$. 623.644,30 juta rupiah, sedangkan di tahun 2015 belanja modal mengalami peningkatan yang cukup signifikan sebesar $223,01 \%$ dengan total belanja modal pada tahun 2015 sebesar Rp. 2.014.487,64 juta rupiah. Besarnya alokasi belanja modal dipengaruhi oleh seberapa besar belanja daerah yang dianggarkan pemerintah daerah dalam Anggaran Pendapatan dan Belanja Daerah Provinsi Riau Tahun 2007-2017.

\section{TREN RASIO BELANJA MODAL}

Rasio belanja modal merupakan perbandingan antara total realisasi belanja modal dengan total belanja daerah. Belanja modal memberikan manfaat jangka menengah dan jangka panjang juga bersifat rutin. Menurut Mahmudi (2009), pada umumnya proporsi belanja modal dengan belanja daerah adalah antara 5-20\%. 


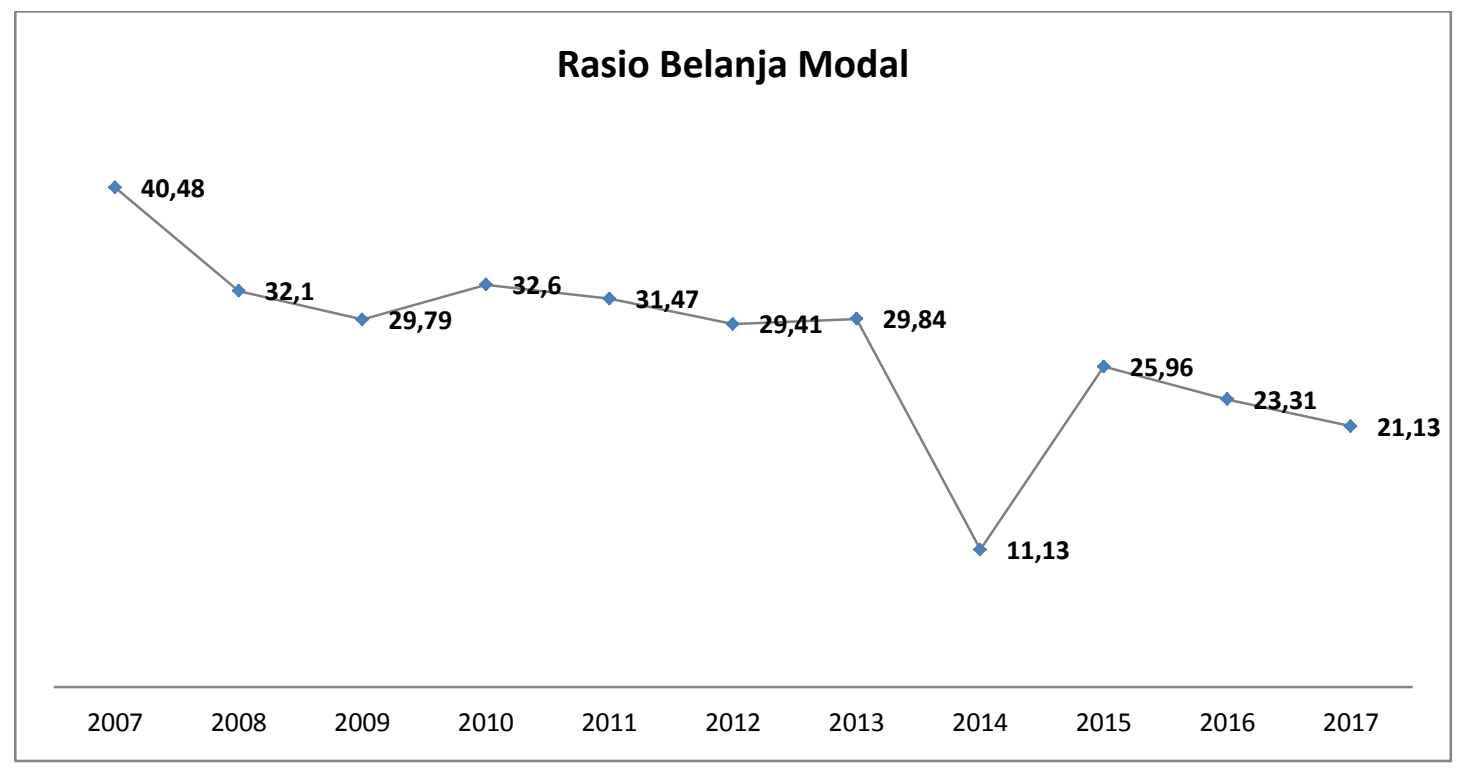

Sumber: Badan Pusat Statistik Provinsi Riau (Riau Dalam Angka), 2018

Gambar 3. Rasio Belanja Modal Provinsi Riau Tahun 2007-2017

Rasio belanja modal Provinsi Riau tahun 2007-2017 mengalami fluktuasi dengan trend menurun dimana rasio tertingi terjadi pada tahun 2007 sebesar $40,48 \%$ kemudian mengalami penurunan sehingga terendah terjadi pada tahun 2014 sebesar $11,13 \%$. Semakin tinggi belanja modal yang dianggarkan dalam APBD, maka semakin tinggi pula kegiatan pembangunan yang akan dilakukan di daerah tersebut, karena belanja modal merupakan penggerak perekonomian daerah.

Menurunnya rasio belanja modal Provinsi Riau tahun 2007-2017 disebabkan oleh alokasi belanja operasi dalam APBD lebih besar dibandingkan dengan alokasi belanja modal, dari tahun 2007-2017 belanja operasi selalu lebih besar dibandingkan dengan belanja modal. Seharusnya pemerintah daerah Provinsi Riau lebih meningkatkan belanja modal dibandingkan dengan belanja operasi, karena belanja modal merupakan belanja publik yang digunakan untuk membangun sarana dan prasarana (infrastruktur) untuk kesejahteraan masyarakat dan meningkatkan kegiatan perekonomian dalam masyarakat yang nantinya dapat mendorong perekonomian daerah.

\section{TREN RASIO BELANJA MODAL PER KAPITA}

Belanja modal yang dilakukan oleh pemerintah daerah juga digunakan di antaranya untuk pembangunan dan perbaikan infrastruktur dalam sektor pendidikan, kesehatan dan transportasi sehingga masyarakatpun turut menikmati manfaat dari pembangunan daerah. Tersedianya infrastruktur yang baik diharapkan dapat menciptakan efisiensi dan efektifitas di berbagai sektor tersebut, produktivitas masyarakat menjadi semakin tinggi dan pada akhirnya terjadi peningkatan pertumbuhan ekonomi (Abimanyu, 2005). 


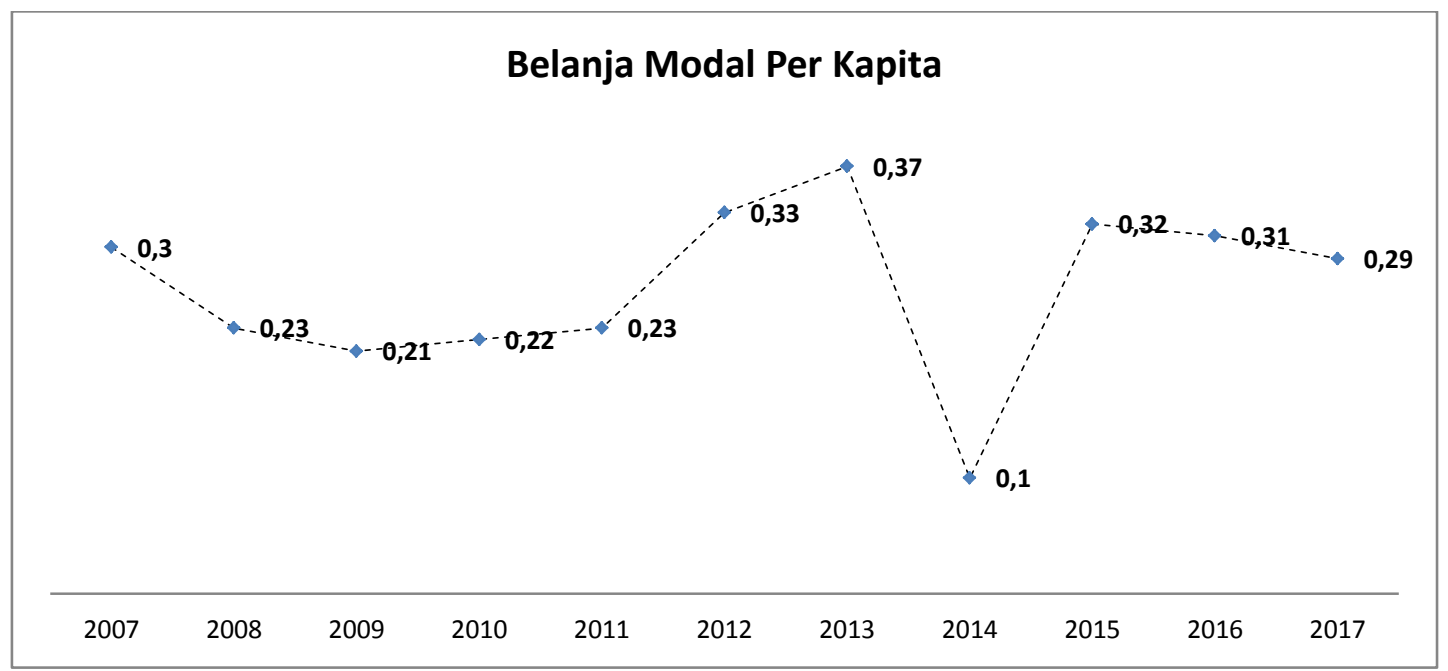

Sumber: Badan Pusat Statistik Provinsi Riau (Riau Dalam Angka), 2018

Gambar 4. Rasio Belanja Modal Per Kapita Provinsi Riau Tahun 2007-2017

Hubungan rasio belanja modal terhadap jumlah penduduk merupakan perbandingan antara jumlah penduduk dengan belanja modal. Rasio ini menggambarkan seberapa besar perhatian pemerintah daerah dalam meningkatkan perekonomian masyarakat melalui pembangunan infrastruktur (Adhiatma, 2013).

Berdasarkan Gambar 4, belanja modal per kapia Provinsi Riau tahun 20072017 berfluktuatif dengan trend meningkat, dimana belanja modal perkapita tertinggi terdapat pada tahun 2013 sebesar Rp. 0,37 juta rupiah dengan belanja modal sebesar Rp. 2.245.307,02 juta rupiah dengan jumlah penduduk pada saat itu 6.125.283 jiwa dan belanja modal per kapita terendah terdapat pada tahun 2014 sebesar Rp. 0,10 juta rupiah, dengan belanja modal sebesar Rp. 623.644,30 dengan jumlah penduduk provinsi Riau pada saat itu sebesar 6.188.442 jiwa.

Pengeluaran belanja daerah dilihat dari perkembangan jumlah penduduk disuatu daerah, apabila perkembangan jumlah penduduk semakin besar akan memerlukan anggaran yang semakin besar. Karena meningkatnya jumlah penduduk menuntut konsekuensi logis adanya peningkatan sarana dan prasarana umum, baik dari aspek kuantitas maupun kualitas. Perkembangan jumlah penduduk yang semakin besar, supaya kualitas pertumbuhan ekonomi lebih baik, pertumbuhan penduduk harus selalu dikendalikan (Gorahe et al., 2013).

Rasio belanja modal per kapita menunjukan seberapa besar belanja yang dialokasikan pemerintah untuk pembangunan infrastruktur daerah per penduduk. Rasio belanja modal per kapita memiliki hubungan yang erat dengan pertumbuhan ekonomi karena belanja modal merupakan salah satu jenis belanja pemerintah yang menjadi pendorong pertumbuhan ekonomi. Rasio ini bermanfaat untuk menunjukan perhatian pemerintah dalam meningkatkan perekonomian penduduknya dari pembangunan infrastruktur yang keluarkan (Nurmainah, 2013).

\section{TREND RASIO BELANJA MODAL TERHADAP PDRB}

Dana pembangunan suatu daerah berasal dari anggaran belanja modal yang di anggarkan oleh pemerintah daerah berupa pembentukan modal yang sifatnya menambah aset tetap/ investasi yang memberikan manfaat lebih dari satu periode akuntansi, termasuk di dalamnya adalah pengeluaran untuk biaya pemeliharaan 
yang sifatnya mempertahankan atau menambah masa manfaat, dan kualitas asset. Rasio belanja modal terhadap PDRB Provinsi Riau tahun 2007-2017 mengalami trend yang menurun di setiap tahunnya pada tahun 2014 paling rendah sebesar 0,32\% dan tertinggi terjadi pada tahun 2015 sebesar 0,59\%.

Pengeluaran pemerintah memiliki kedudukan yang strategis dalam meningkatkan laju pertumbuhan ekonomi, belanja modal dapat memainkan peran sebagai salah satu penggerak utama dalam perekonomian, sehingga ketika perekonomian sedang mengalami kelesuan akibat adanya resesi ekonomi yang memerosotkan kemampuan masyarakat dalam melakukan kegiatan perekonomian, pemerintah melalui instrumen kebijakan yang dimiliki dapat tampil menyelamatkan keadaan dengan memperbesar pengeluaran pemerintah (Swaramarinda \& Indriani, 2011). Dengan demikian, dapat dikatakan bahwa semakin tinggi belanja modal pemerintah, maka semakin tinggi tingkat kegiatan ekonomi dalam masyarakat yang pada akhirnya akan mendorong pertumbuhan PDRB per kapita.

Pembangunan dalam sektor pelayanan publik akan meransang masyarakat untuk lebih aktif dan bergairah dalam bekerja karena ditunjang oleh fasilitas yang memadai selain itu investor juga akan tertarik kepada daerah karena fasilitas yang diberikan oleh daerah. dengan bertambahnya produktifitas masyarakat dan infestor yang berada di daerah akan berdampak pada peningkatan Pendapatan Asli Daerah (PAD). PAD yang semakin tinggi akan meransang pemerintah daerah untuk lebih meningkatkan mutu pelayanannya kepada publik sehingga tingkat pertumbuhan ekonomi daerah akan meningkat seiring dengan meningkatnya pendapatan per kapita (Deviani, 2016).

\section{KESIMPULAN}

Belanja modal Provinsi Riau terbesar dialokasikan ke belanja modal jalan, irigasi dan jaringan. Pada tahun 2007 rasio belanja modal terhadap belanja mencapai $40,48 \%$, kemudian turun hingga $11,13 \%$ pada tahun 2014 . Rata-belanja modal per kapita hanya Rp.270 ribu pert haun selama peridoe pengamatan, bahkan pada 2014 hanya sebesar Rp.100 ribu. Trend rasio belanja modal terhadap PDRB tahun 2007-2017 menurun, sedangkan belanja operasional terus meningkat.

Belanja modal berupa infrastuktur publik mendorong perekonomian daerah, maka diharapkan memberikan dampak positif terhadap pertumbuhan ekonomi. Pemerintah Daerah Provinsi Riau harus memperhatikan penetapan strategi pengalokasian dan pendistribusian belanja modal agar meningkatkan pertumbuhan ekonomi.

\section{DAFTAR PUSTAKA}

(1) Abimanyu. (2005). Analisis pengaruh dana alokasi umum dan pendapatan asli daerah terhadap prediksi belanja daerah: studi empiric di wilayah Provinsi Jawa Tengah dan DIY. JAAI 8(2), 416-424.

(2) Adhiatma, M. S. (2013). Spending behavior pemerintah Kabupaten/Kota se ekskaresidenan Semarang tahun anggaran 2008-2012. Jurnal Ekonomi 3(2), 12-22.

(3) Adhikari, P., Kuruppu, C., Wynne, A., \& Ambalangodage, D. (2015). Diffusion of the cash basis International Public Sector Accounting Standard (IPSAS) in Less Developed Countries (LDCs)-The case of the Nepali Central Government. The Public Sector Accounting, Accountability and Auditing in Emerging Economies 15, 85-108. 
(4) Almquist, R., Grossi, G., van Helden, G. J., \& Reichard, C. (2013). Public sector governance and accountability. Critical Perspectives on Accounting 24(7-8), 479-487.

(5) Astiti, D. N., \& Mimba, N. S. (2016). Pengaruh Belanja Rutin dan Belanja Modal pada Kinerja Keuangan Pemerintah Daerah. E Jurnal Akuntansi 14(3), 1924-1950.

(6) Bado, B. (2016). Analisis belanja modal, investasi, dan tenaga kerja terhadap pertumbuhan ekonomi Sulawesi Selatan. Ecosains, 118-126.

(7) Chang, L. (2009). The impact of political interests upon the formulation of performance measurements: The NHS star rating system. Financial Accountability and Management 25 (2), 145-165.

(8) Deviani. (2016). Analisis belanja daerah terhadap pertumbuhan ekonomi dan pendidikan (studi empiris Kota dan Kabupaten di Sumatra Barat). Pekbis Jurnal 8(1), 1-13.

(9) Fryer, K., Ogden, J., \& Fryer, K. (2009). Performance management in the public sector. International Journal of Public Sector Management 22(6), 479-498.

(10) Gorahe, I., Marsudi, A., Misinamow, V., \& Daisy, E. (2013). Analisis belanja daerah dan faktor-faktor yang mempengaruhinya di Provinsi Sulawesi Utara. Efisiensi 4 (3), 1 12.

(11) Jones, R., \& Pendlebury, M. (2000). Public Sector Accounting. Essex: Pearson Education.

(12) Keefer, P., \& Khemani, S. (2003). The political economy of public expenditures. Background paper for WDR 2004: Making Service Work for Poor People. New York: The World Bank.

(13) Kelly, J. M., \& Rivenbank, W. C. (2011). Performance budgeting for state and local government (2nd Edition). New York: M.E. Sharpe.

(14) Lapsley, I., \& Pallot, J. (2002). Accounting, management and organizational change: A comparative study of local government. Management Accounting Research, 213-222.

(15) Lapsley, I., Miller, P., \& Panozzo, F. (2010). Accounting for the city. Accounting, Auditing and Accountability Journal 23(3), 305-324.

(16) Mahmudi. (2009). Manajemen keuangan daerah. Yogyakarta: Erlangga.

(17) Meirene, A. H., Pangemanan, S. S., \& Dullo, A. (2014). Perlakuan belanja modal pada DPPKAD Pemda Kota Palu. Jurnal EMBA 2(3), 411-419.

(18) Nurmainah, S. (2013). Analisis pengaruh belanja modal belanja modal pemerintah daerah, tenaga kerja terserap dan indeks pembangunan manusia terhadap pertumbuhan dan kemiskinan. Jurnal Bisnis dan Ekonomi 20(2), 131-141.

(19) Sugiyanta. (2016). Analisis belanja modal dan faktor-faktor yang mempengaruhinya pada Kabupaten/Kota di Indonesia. Jurnal Akuntansi 14(1), 19-40.

(20) Suryani, F., \& Eka, P. (2018). Pengaruh pendapatan asli daerah dan dana alokasi umum terhadap belanja modal pada Kabupaten/Kota di Provinsi Riau. Jurnal Pendidikan Ekonomi Akuntansi 6(1), 11-22.

(21) Swaramarinda, D. R., \& Indriani, S. (2011). Pengaruh pengeluaran konsumsi dan investasi pemerintah terhadap pertumbuhan ekonomi di Indonesia. Ecosains 9(2), 95105.

(22) Tuasikal, A. (2008). Pengatuh DAU, DAK dan PDRB terhadap belanja modal pemerintah daerah Kabupaten/kota di Indonesia. Telaah dan Riset Akuntansi 1(2), 142-154.

(23) Yuliastati, K. (2017). Urgensi anggaran pendapatan belanja dearah (APBD) terhdap perencanaan pemvangunan daerah. Jurnal Katalogis 5(4), 160-171. 